\title{
The Sexual Development and Education of Preschool Children: Knowledge and Opinions from Doctors and Nurses
}

\author{
Meltem Kurtuncu • Latife Utas Akhan • İbrahim Murat Tanir • \\ Hicran Yildiz
}

Published online: 22 January 2015

(C) The Author(s) 2015. This article is published with open access at Springerlink.com

\begin{abstract}
This descriptive study was carried out in order to determine the knowledge levels and attitudes of doctors and nurses regarding children's sexual development and sex education. The study was conducted with doctors and nurses who work at various clinics of two state hospitals located in the province of Istanbul. The data collection tool consisted of 58 questions. The Statistical Program for the Social Sciences, version 18.0 (SPSS 18.0) was used for data analysis. It was determined that females comprised the majority of the respondents $(61 \%)$ and were over 36 years of age $(54.1 \%)(37.81 \pm 8.82)$. Of the participants in the study, $63.5 \%$ had bachelor's degrees and $62.1 \%$ were medical doctors. It was determined that the number of correct responses given by the respondents regarding some behaviors observed in children aged between 3 and 6 years and children's sexual development and sex education showed significant differences according to age group $(p=0.007)$, marital status $(p=0.004)$, the status of having children $(p=0.004)$, educational status $(p=0.005)$ and occupation $(p=0.000)$. However, in a review of the study findings, it was observed that culture had an important impact on sex-related approaches and that embarrassment and shyness is very common.
\end{abstract}

Keywords Children - Sexual development - Sexual education - Preschool period · Turkey

\footnotetext{
M. Kurtuncu $(\bowtie) \cdot$ L. U. Akhan

Department of Pediatric Nursing, Zonguldak School of Nursing, Bülent Ecevit University, Zonguldak, Turkey

e-mail: mkurtuncu@marmara.edu.tr

L. U. Akhan

e-mail: latifeutasakhan@hotmail.com

I. M. Tanir

Sultanbeyli State Hospital, Istanbul, Turkey

e-mail:drtanir@gmail.com

H. Yildiz

Division of Nursing, Health Science Faculty, Uludag University, Bursa, Turkey

e-mail: hicran_yildiz@yahoo.com
} 


\section{Introduction}

The preschool period is the time when a child meets, learns about, and communicates first with his close environment and family and then with the extended family and the whole environment [1,2]. The period particularly between the ages of $0-6$, which is known as the early childhood period (preschool period), is a very critical period where learning is fastest, the child is affected the most from environmental factors, and the chance is highest that the child will maintain acquired attitudes, behavior and habits in the following years [1]. In this period when the basis of the child's personality is formed, the child needs guidance from a source knowledgeable about areas of development. One of those areas is the sexual development of the child. As with many other subjects, placing importance on sexual education in this period has many benefits in terms of development [3-5].

The concept of sexuality is generally attributed to adolescence and kept separate from childhood. However, sexuality does not emerge suddenly during adolescence; it starts from the moment a baby is born [6]. In adolescence, knowledge and attitudes about sexuality change under the impact of environmental factors, going beyond the individual's own thoughts and perceptions [7, 8]. Parents, teachers, families, neighbors and the media all have important roles in the sexual education of children and give children sexual education from birth without even noticing that they are doing so [4, 8-13]. Studies have confirmed that sexual education is a lifelong process that starts at birth [14, 15].

Bulut [16] stated that the sexual education of children has been long neglected, most probably because children do not have the ability to reproduce. Artan [17] has suggested that the term "sexual education" primarily conjures up the idea of reproduction and thus, having sex. However, when the definition of sexual identity is considered, it is very clear that the context of sexual education should be very different [3].

There are different ideas on whether or not preschool children should receive sexual education, which topics such an education would include, and at what age such education should be started. In particular, parental awareness of the role they play in the personal development of their children will have a positive effect on their children's sexual development. A child who receives sexual education in phases in a manner appropriate to his/her age would be expected to be more stable in his/her relationships with the opposite sex in later life [15].

There have not been sufficient studies in Turkey on the sexual education of children. Efforts aiming to raise awareness and provide knowledge to families have also been insufficient. It can be seen that there are many more studies on the subject in other countries where these topics are included in educational programs [18, 19].

Doctors and nurses who work in healthcare are in an important position to achieve the early diagnosis of high-risk children and families. Health professionals working in hospital units are the first to encounter children and families [20]. An important role falls on the shoulders of health professionals in educating children about sexual development and in preparing and handing out booklets to families via family health centers [21]. Thus, it is important to know the extent of knowledge of doctors and nurses and their attitudes on the sexual development and education of children.

This study was performed in order to determine the knowledge, attitudes, and opinions of doctors and nurses working in health care who are in a unique position to reach parents regarding the sexual development and education of their children. 


\section{Materials and Methods}

\section{Study Group and Sample Size}

This descriptive study was carried out in order to determine knowledge levels and attitudes of doctors and nurses regarding children's sexual development and sex education. The study was conducted with doctors and nurses working at the various clinics of two state hospitals located in the province of Istanbul. A total of 138 doctors and 150 nurses work at these hospitals. The study was completed with the participation of 104 doctors and 55 nurses since some of them were on vacation, were absent due to sickness, or did not wish to participate in the study.

\section{Collection of Data}

The data collection tool consisted of 58 questions and was prepared by the researcher based on published literature and the opinions of two experts $[2,3,5]$. The questionnaire consisted of three sections: The first section included seven questions about the demographic characteristics of the doctors and nurses; the second section included five questions about the knowledge of the doctors and nurses regarding children's sexual development and sex education. The third section included 46 items on some sexual behaviors of children, children's sexual development, and sex education. The choices in the third section were "True", "False", and "I do not know". A test run of the questionnaire was carried out with ten people. Data pertaining to the participants taking part in the test run were excluded from the study.

\section{Implementation of the Data Collection Tool}

This study was conducted between October and November 2013. The researchers visited clinics during the night and day shifts and gave the questionnaire to doctors and nurses who agreed to participate in the study. The aim of the study was explained to the participants, who completed the forms individually. Filling out the questionnaire took an average of $15 \mathrm{~min}$. The completed forms were received in sealed envelopes.

\section{Assessment of Data}

The Statistical Program for the Social Sciences Version 18.0 (SPSS 18.0) was used for data analysis. In addition, we calculated percentages and averages and performed the Kruskall Wallis-H, Mann-Whitney U and Tukey HSD tests for statistical analysis.

\section{Ethical Aspects of the Study}

Written permission was obtained from the hospitals where the study was conducted. In the light of the principle of autonomy, "informed consent" was obtained from the doctors and nurses after explaining the study's aim, plan, and its expectations from the participants. Participation in the study was voluntary. We told the participants that they were free to participate or not participate, that they could withdraw from the study at any point and that they had the right to abstain from providing information. The "loyalty-privacy" principle was upheld by reassuring the participants that their personal information would not be 
revealed to anyone other than the researchers or that no one else would be permitted others to access this information.

\section{Findings}

In this study, which was conducted in order to determine knowledge levels, attitudes, and opinions regarding sex education for children among doctors and nurses working in health services who are in an important position to reach parents with regard to children's sexual development and sex education, we reached the following results.

\section{Sociodemographic Characteristics}

It was determined that the females comprised the majority of the respondents $(61 \%)$ and were over the age of 36 years $(54.1 \%)(37.81 \pm 8.82)$. Of the respondents, $81.1 \%$ were married and $89.4 \%$ were members of a nuclear family. Among the married participants, $80.5 \%$ had children and most (41.4\%) had two children. Another $63.5 \%$ had bachelor's degrees and $62.1 \%$ were medical doctors (Table 1).

\section{Sexual Education}

Of the respondents, $93.1 \%$ thought that it is necessary to provide sex education for children. The majority $(54.7 \%)$ stated that sex education for children should start at the ages of 7-12 years and $30.8 \%$ thought that parents should provide this education. Another $6.3 \%$ had attended a training program on sex education for children and $30 \%$ reported that they received this training during undergraduate study.

\section{Attitudes Toward Sexual Education}

Of the respondents, $85.2 \%$ reported that they had waited for their children to ask questions in order to inform them about sexuality and $70.3 \%$ stated that they talked to their children on any topic related to sexuality. Among the study participants, the most common topic talked about with children was "bodily differences between genders" and the topic least talked about was "masturbation" (Table 2).

When we examined the distribution of the opinions of the respondents regarding some behaviors observed in children between the ages of 3-6 years and the topic of children's sexual development and sex education (Table 3), we found that the respondents found the statement "Children aged between 5 and 6 years may try to touch their mothers' or other women's breasts" the most accurate statement (96.2\%) and that the statement "Sexuality and sex education starts during adolescence" was perceived as the most inaccurate statement $(71.1 \%)$. The mean total accurate response score was found to be $33.15 \pm 5.70$.

It was determined that the number of correct responses given by the respondents regarding some behaviors observed in children between the ages of 3-6 years and children's sexual development and sex education showed significant differences according to age group, marital status, the status of having children, educational status, and occupation (Table 4).

The number of correct answers is less in the single respondents than in the married and divorced. The number of correct answers in the age group 25 and under is less than in the 
Table 1 Distribution of sociodemographic characteristics among cases $(\mathrm{N}=159)$

\begin{tabular}{|c|c|c|}
\hline Socio-demographic characteristics & $\mathrm{n}$ & $\%$ \\
\hline \multicolumn{3}{|l|}{ Gender } \\
\hline Female & 97 & 61.0 \\
\hline Male & 62 & 39.0 \\
\hline \multicolumn{3}{|l|}{ Age } \\
\hline 25 and $\downarrow$ & 7 & 4.4 \\
\hline $26-30$ years & 26 & 16.4 \\
\hline $31-35$ years & 40 & 25.2 \\
\hline 36 and $\uparrow$ & 86 & 54.1 \\
\hline \multicolumn{3}{|l|}{ Age } \\
\hline$(\bar{X} \pm \mathrm{SD}$ years $)$ & $37.81 \pm 8.82$ & (Range: 18-62) \\
\hline \multicolumn{3}{|l|}{ Marital status } \\
\hline Married & 129 & 81.1 \\
\hline Single & 26 & 16.4 \\
\hline Divorced & 4 & 2.5 \\
\hline \multicolumn{3}{|l|}{ Family type } \\
\hline Nuclear family & 135 & 84.9 \\
\hline Extended family & 20 & 12.6 \\
\hline Single parent & 4 & 2.5 \\
\hline \multicolumn{3}{|l|}{ Do you have children? } \\
\hline Yes & 128 & 80.5 \\
\hline No & 31 & 19.5 \\
\hline \multicolumn{3}{|l|}{ Number of children $(n=128)$} \\
\hline 1 & 49 & 38.3 \\
\hline 2 & 53 & 41.4 \\
\hline 3 & 22 & 17.2 \\
\hline 4 and more & 4 & 3.1 \\
\hline \multicolumn{3}{|l|}{ Educational status } \\
\hline Vocational school of health & 12 & 7.5 \\
\hline Associate of science & 10 & 6.3 \\
\hline Bachelor's degree & 101 & 63.5 \\
\hline Other & 36 & 22.6 \\
\hline \multicolumn{3}{|l|}{ Occupation } \\
\hline Doctor & 104 & 65.4 \\
\hline Nurse & 55 & 34.6 \\
\hline
\end{tabular}

age groups 31-35 and 36 and above. The number of correct answers is higher in the group of university graduate respondents compared to other graduates.

The number of correct responses given by the respondents regarding some behaviors observed in children of the ages 3-6 and children's sexual development and sex education showed significant differences according to whether or not the respondents thought it was necessary to provide children with sex education and whether or not they talked to children about any topic related to sexuality (Table 5). 
Table 2 Distribution of opinions and approaches regarding sexuality among cases $(\mathrm{N}=159)$

\begin{tabular}{lll}
\hline Thoughts about sex education & $\mathrm{n}$ & $\%$ \\
\hline
\end{tabular}

Do you think it is necessary to provide sex education for children?

Yes

No

At what age do you think sex education should be started?

$0-3$ years

$2 \quad 1.3$

4-6 years

$63 \quad 39.6$

$7-12$ years

13-18 years

Who should provide sex education for your child?

Mother-father

$\begin{array}{ll}49 & 30.8\end{array}$

School

21.3

An expert

Parents and schools

Parents, school and experts

Parents and experts

Did you receive training on children's sex education before?

Yes

No

From whom did you receive this training and how long was the training program? $(\mathrm{n}=10)$

From an expert friend for a short period

20.0

During undergraduate study

330.0

During my specialization in medicine

$1 \quad 10.0$

From a private institution for 6 months

$1 \quad 10.0$

From a private center for a month

From a psychiatrist friend for a short period

$1 \quad 10.0$

From a psychologist

110.0

$1 \quad 10.0$

Do you wait for your child to ask questions in order to provide information on sexuality?

I wait for him/her to ask questions

I do not wait for him/her to ask questions

Have you talked to your child about any sexuality related topic?

Yes

No

Which topics did you talk with your child? $(\mathrm{n}=90)^{\mathrm{a}}$

Bodily differences between genders

Pregnancy and birth

Reproduction

Slang and swear words

Masturbation

Sexual abuse

Health and hygiene rules

$79 \quad 87.8$

Sexual curiosity and games (marital games and playing doctor)

$54 \quad 60.0$ 
Table 2 continued

\begin{tabular}{lrr}
\hline Thoughts about sex education & $\mathrm{n}$ & $\%$ \\
\hline AIDS & 13 & 14.4 \\
Other sexually transmitted diseases & 15 & 16.7 \\
\hline
\end{tabular}

${ }^{\text {a }}$ More than one choice was marked

Table 3 Distribution of opinions regarding some behaviors observed in children aged between 3 and 6 years, sexual development and sex education $(\mathrm{N}=159)$

\begin{tabular}{|c|c|c|c|c|c|c|}
\hline & \multicolumn{2}{|l|}{ True } & \multicolumn{2}{|c|}{ False } & \multicolumn{2}{|c|}{ I do not know } \\
\hline & $\mathrm{n}$ & $\%$ & $\mathrm{n}$ & $\%$ & $\mathrm{n}$ & $\%$ \\
\hline $\begin{array}{l}\text { Children who are } 6 \text { years old may try to } \\
\text { perform sexual behaviors they see on } \\
\text { (kissing, sleeping together, etc.) }\end{array}$ & 150 & 94.3 & 9 & 5.7 & - & - \\
\hline $\begin{array}{l}\text { Sexual development and sex education } \\
\text { start during the maternal period and } \\
\text { continues through the life span }\end{array}$ & 150 & 94.3 & 9 & 5.7 & - & - \\
\hline $\begin{array}{l}\text { Children aged between } 5 \text { and } 6 \text { years } \\
\text { may try to touch their mothers' or } \\
\text { other women's breasts }\end{array}$ & 153 & 96.2 & 6 & 3.8 & - & - \\
\hline $\begin{array}{l}\text { The first information on sexuality } \\
\text { should be provided by parents for } \\
\text { their children }\end{array}$ & 150 & 94.3 & 9 & 5.7 & - & - \\
\hline $\begin{array}{l}\text { Children's and adults' sexual behaviors } \\
\text { are not similar and are not performed } \\
\text { for the same purposes }\end{array}$ & 143 & 89.9 & 13 & 8.2 & 3 & 1.9 \\
\hline $\begin{array}{l}\text { Children aged between } 5 \text { and } 6 \text { years } \\
\text { sometimes may try to kiss other } \\
\text { children or peers by force }\end{array}$ & 139 & 87.4 & 17 & 10.7 & 3 & 1.9 \\
\hline $\begin{array}{l}\text { Children should be oriented toward } \\
\text { choosing gender appropriate clothes. } \\
\text { Toys, colors, etc. }\end{array}$ & 139 & 87.4 & 16 & 10.1 & 4 & 2.5 \\
\hline $\begin{array}{l}\text { Children aged between } 5 \text { and } 6 \text { years } \\
\text { may try to undress other children or } \\
\text { peers }\end{array}$ & 122 & 76.7 & 23 & 14.5 & 14 & 8.8 \\
\hline $\begin{array}{l}\text { Sex education should be provided at } \\
\text { kinder garden }\end{array}$ & 127 & 79.9 & 19 & 11.9 & 13 & 8.2 \\
\hline $\begin{array}{l}\text { Girls' effort to look like their mothers } \\
\text { and boys' effort to look like their } \\
\text { fathers is called identification and this } \\
\text { process takes place in order to adopt } \\
\text { sexual identity during 3-6 years of } \\
\text { age }\end{array}$ & 130 & 81.8 & 17 & 10.7 & 12 & 7.5 \\
\hline $\begin{array}{l}\text { Children aged between } 3 \text { and } 6 \text { years } \\
\text { may try to Show their genitals to } \\
\text { other children or peers or adults }\end{array}$ & 121 & 76.1 & 28 & 17.6 & 10 & 6.3 \\
\hline $\begin{array}{l}\text { Sexual abuse is an adults' sex-oriented } \\
\text { approach toward a child and involves } \\
\text { sex related acts. expressions and } \\
\text { thoughts }\end{array}$ & 127 & 79.9 & 19 & 11.9 & 13 & 8.2 \\
\hline
\end{tabular}


Table 3 continued

\begin{tabular}{|c|c|c|c|c|c|c|}
\hline & \multicolumn{2}{|c|}{ True } & \multicolumn{2}{|c|}{ False } & \multicolumn{2}{|c|}{ I do not know } \\
\hline & $\mathrm{n}$ & $\%$ & $\mathrm{n}$ & $\%$ & $\mathrm{n}$ & $\%$ \\
\hline $\begin{array}{l}\text { It is important for the development of } \\
\text { children aged between } 5 \text { and } 6 \text { years } \\
\text { to know names of body parts and } \\
\text { their functions }\end{array}$ & 131 & 82.4 & 19 & 11.9 & 9 & 5.7 \\
\hline Children do not have sexual instincts & 37 & 23.3 & 97 & 61.0 & 25 & 15.7 \\
\hline $\begin{array}{l}\text { Children aged between } 5 \text { and } 6 \text { years } \\
\text { can define/explain their gender } \\
\text { according to cultural characteristics }\end{array}$ & 137 & 86.2 & 13 & 8.2 & 9 & 5.7 \\
\hline $\begin{array}{l}\text { Children do not need sex education } \\
\text { before the age of 5-6 }\end{array}$ & 123 & 77.4 & 29 & 18.2 & 7 & 4.4 \\
\hline $\begin{array}{l}\text { It is normal for children aged between } 5 \\
\text { and } 6 \text { years to play doctor and marital } \\
\text { games and during these games } \\
\text { children can take off their clothes and } \\
\text { inspect each other's body }\end{array}$ & 144 & 90.6 & 11 & 6.9 & 11 & 6.9 \\
\hline $\begin{array}{l}\text { Children start to ask questions about the } \\
\text { father's role and contribution } \\
\text { regarding birth after the age of } 4\end{array}$ & 129 & 81.1 & 15 & 9.4 & 15 & 9.4 \\
\hline $\begin{array}{l}\text { Children aged between } 5 \text { and } 6 \text { years } \\
\text { can make gender appropriate toy } \\
\text { choices }\end{array}$ & 149 & 93.7 & 7 & 4.4 & 3 & 1.9 \\
\hline $\begin{array}{l}\text { Children aged between } 5 \text { and } 6 \text { years } \\
\text { may sometimes use sex related slang } \\
\text { words }\end{array}$ & 137 & 86.2 & 15 & 9.4 & 7 & 4.4 \\
\hline $\begin{array}{l}\text { Sexuality is a healthy and natural part } \\
\text { of life that starts at birth and } \\
\text { continues through the life span }\end{array}$ & 142 & 89.3 & 14 & 8.8 & 3 & 1.9 \\
\hline $\begin{array}{l}\text { Children ask questions about sexuality } \\
\text { (questions about birth and pregnancy } \\
\text { such as "where do babies come } \\
\text { from?") before the age of } 6 \text { (at ages } \\
2.5-3 \text { in particular) }\end{array}$ & 135 & 84.9 & 21 & 13.2 & 3 & 1.9 \\
\hline $\begin{array}{l}\text { Sexuality and sex education start during } \\
\text { adolescence }\end{array}$ & 41 & 25.8 & 113 & 71.1 & 5 & 3.1 \\
\hline $\begin{array}{l}\text { Sucking the mother's breast is the first } \\
\text { sexual experience of the baby }\end{array}$ & 67 & 42.1 & 76 & 47.8 & 16 & 10.1 \\
\hline $\begin{array}{l}\text { Parents, teachers and caregivers should } \\
\text { be in cooperation in terms of sex } \\
\text { education }\end{array}$ & 133 & 83.6 & 16 & 10.1 & 10 & 6.3 \\
\hline $\begin{array}{l}\text { Children aged between } 5 \text { and } 6 \text { years } \\
\text { are curious about other people's rest } \\
\text { room and bathing activities and may } \\
\text { try to observe them. }\end{array}$ & 137 & 86.2 & 13 & 8.2 & 9 & 5.7 \\
\hline $\begin{array}{l}\text { Babies touch their genitals when their } \\
\text { diaper is changed and they enjoy this. } \\
\text { This behavior is the beginning of } \\
\text { taking pleasure }\end{array}$ & 126 & 79.2 & 21 & 13.2 & 12 & 7.5 \\
\hline $\begin{array}{l}\text { Children aged between } 3 \text { and } 6 \text { years } \\
\text { take pleasure in touching their own } \\
\text { genitals and being naked }\end{array}$ & 127 & 79.9 & 19 & 11.9 & 13 & 8.2 \\
\hline
\end{tabular}


Table 3 continued

\begin{tabular}{|c|c|c|c|c|c|c|}
\hline & \multicolumn{2}{|c|}{ True } & \multicolumn{2}{|c|}{ False } & \multicolumn{2}{|c|}{ I do not know } \\
\hline & $\mathrm{n}$ & $\%$ & $\mathrm{n}$ & $\%$ & $\mathrm{n}$ & $\%$ \\
\hline $\begin{array}{l}\text { Children should be punished when they } \\
\text { use slang words with sexual content }\end{array}$ & 81 & 50.9 & 60 & 37.7 & 18 & 11.3 \\
\hline $\begin{array}{l}\text { Sex education should be provided when } \\
\text { children start to ask questions about } \\
\text { sexuality }\end{array}$ & 129 & 81.1 & 16 & 10.1 & 14 & 8.8 \\
\hline $\begin{array}{l}\text { Children ask questions about the } \\
\text { differences of girls' boys' bodies } \\
\text { before the age of } 6 \text { (at ages } 2.5-3 \text { in } \\
\text { particular) }\end{array}$ & 129 & 81.1 & 16 & 10.1 & 14 & 8.8 \\
\hline $\begin{array}{l}\text { Children who are } 6 \text { years old choose } \\
\text { clothes appropriate for their gender }\end{array}$ & 130 & 81.8 & 15 & 9.4 & 14 & 8.8 \\
\hline $\begin{array}{l}\text { Children should learn to name their } \\
\text { body parts in an appropriate and } \\
\text { decent fashion instead calling these } \\
\text { body parts with their real names }\end{array}$ & 130 & 81.8 & 21 & 13.2 & 8 & 5.0 \\
\hline $\begin{array}{l}\text { Children aged between } 5 \text { and } 6 \text { years } \\
\text { choose gender appropriate roles in } \\
\text { games }\end{array}$ & 137 & 86.2 & 11 & 6.9 & 11 & 6.9 \\
\hline $\begin{array}{l}\text { Parents are more responsible in } \\
\text { providing sex education for children } \\
\text { compared to schools }\end{array}$ & 134 & 84.3 & 13 & 8.2 & 12 & 7.5 \\
\hline $\begin{array}{l}\text { In children aged between } 5 \text { and } 6 \text { years, } \\
\text { mothers should answer girls' } \\
\text { questions on sexuality and fathers } \\
\text { should answer boys' questions }\end{array}$ & 125 & 78.6 & 25 & 15.7 & 9 & 5.7 \\
\hline $\begin{array}{l}\text { Masturbation is a part of childhood } \\
\text { development }\end{array}$ & 64 & 40.3 & 73 & 45.9 & 22 & 13.8 \\
\hline $\begin{array}{l}\text { The effect of gender is observed in } \\
\text { friend choices during } 3 \text { years of age }\end{array}$ & 138 & 86.8 & 11 & 6.9 & 10 & 6.3 \\
\hline $\begin{array}{l}\text { Some sexuality related questions of } \\
\text { children aged between } 5 \text { and } 6 \text { years } \\
\text { can be ignored }\end{array}$ & 132 & 83.0 & 23 & 14.5 & 4 & 2.5 \\
\hline $\begin{array}{l}\text { Family's social system provides a } \\
\text { model for children in their } \\
\text { relationships with other people and } \\
\text { teaches them many things }\end{array}$ & 150 & 94.3 & 6 & 3.8 & 3 & 1.9 \\
\hline $\begin{array}{l}\text { It is not appropriate for girls and boys } \\
\text { who are } 6 \text { years old to sleep in the } \\
\text { same room in terms of their } \\
\text { development }\end{array}$ & 134 & 84.3 & 20 & 12.6 & 5 & 3.1 \\
\hline $\begin{array}{l}\text { Only girls can be subject to sexual } \\
\text { abuse }\end{array}$ & 46 & 28.9 & 109 & 68.6 & 4 & 2.5 \\
\hline $\begin{array}{l}\text { Children aged } 5-6 \text { years can bathe with } \\
\text { their peers and parents }\end{array}$ & 116 & 73.0 & 37 & 23.3 & 6 & 3.8 \\
\hline $\begin{array}{l}\text { Most children aged less than } 6 \text { years } \\
\text { and at age } 3 \text { in particular are curious } \\
\text { and talkative about their own and } \\
\text { other people's bodies, experiences } \\
\text { and feelings }\end{array}$ & 146 & 91.8 & 11 & 6.9 & 2 & 1.3 \\
\hline
\end{tabular}


Table 3 continued

\begin{tabular}{|c|c|c|c|c|c|c|}
\hline & \multicolumn{2}{|l|}{ True } & \multicolumn{2}{|l|}{ False } & \multicolumn{2}{|l|}{ I do not know } \\
\hline & $\mathrm{n}$ & $\%$ & $\mathrm{n}$ & $\%$ & $\mathrm{n}$ & $\%$ \\
\hline $\begin{array}{l}\text { Children's love for their caregivers, } \\
\text { teachers or parents can sometimes be } \\
\text { perceived as a romantic feeling }\end{array}$ & 147 & 92.5 & 8 & 5.0 & 4 & 2.5 \\
\hline $\begin{array}{l}\text { If you encounter a scene that includes } \\
\text { sexuality while you are watching } \\
\text { television with your child possible } \\
\text { solutions for this situation are turning } \\
\text { off the television, switching the } \\
\text { channel or closing your child's eyes }\end{array}$ & 137 & 86.2 & 12 & 7.5 & 10 & 6.3 \\
\hline Total number of correct answers & $\bar{X} \pm \mathrm{SD}$ & & $33.15 \pm 5.70$ & & Range $=17-40$ & \\
\hline
\end{tabular}

\section{Discussion}

In a review of studies conducted between 1975 to the present on the topic of preschool children in Turkey, we determined that topics related to sexual development and sex education were never mentioned in earlier studies. It was seen, however, that a small number of studies gradually emerged after the 1980s and the number of these studies continued to increase [22].

\section{Sexual Education}

In the present study, it was found that $93.1 \%$ of the respondents thought that it was necessary to provide children with sex education and the majority $(54.7 \%)$ stated that sex education for children should start at the ages of between 7 and 12 years. Tuğrul and Artan [23] reported that $7.5 \%$ of mothers believed that the sex education of children should start at ages 0-3 while $17.4 \%$ believed this should happen at 3-6 years of age, $39.6 \%$ pointed to the elementary school years as the appropriate time, and $27.8 \%$ thought that the high school years are the best time. In a study El Shaieb and Wurtele [24] conducted with parents, it was determined that families did not talk to their children about sexuality before the ages of 5-7 years. Ages 7-12 correspond to the period that children start to attend elementary school. However, in the literature, it has been reported that providing sex education at early ages would contribute to the formation of healthier sex lives during adulthood [25]. When we look at Freud's developmental stages, we see that sexuality is present at birth and that during the phallic phase (3-6 years of age) behaviors such as masturbation are among the dominant functions of the phase [26]. Experiences pertaining to the earlier stages of life are very influential in the development of a sexual identity. Sexual experience and sexual perception are affected by personal experience and contribute to the development of gender identity [8, 9, 27].

When we examined the responses given to the question "Who should provide sex education for your child?" that was related to the respondent's opinions and approaches regarding sex education, we observed that $40.9 \%$ answered as "An expert should provide sex education for my child" and $30.8 \%$ of the cases responded as "Parents should be the ones to provide their children with sex education." In their study with mothers, Tuğrul and Artan [23] found that $89.8 \%$ of mothers believed that mothers should be the ones to give a 
Table 4 Distribution of differences in the number of correct responses by sociodemographic characteristics $(\mathrm{N}=159)$

\begin{tabular}{|c|c|c|}
\hline Socio-demographic characteristics & $\bar{X} \pm \mathrm{SD}$ & Level of significance \\
\hline Gender & & $\mathrm{U}=2,787.50$ \\
\hline Female & $33.57 \pm 5.66$ & $Z=-0.782$ \\
\hline Male & $32.50 \pm 5.74$ & $p=0.434$ \\
\hline Age group & & $\mathrm{KW}=12.000$ \\
\hline 25 vs. $\downarrow$ & $27.00 \pm 3.55$ & $p=0.007$ \\
\hline 26-30 years & $32.34 \pm 5.79$ & \\
\hline $31-35$ years & $34.85 \pm 5.88$ & \\
\hline 36 vs. $\uparrow$ & $33.11 \pm 5.40$ & \\
\hline Marital status & & $\mathrm{KW}=11.02$ \\
\hline Married & $33.58 \pm 5.70$ & $p=0.004$ \\
\hline Single & $30.30 \pm 5.05$ & \\
\hline Divorced & $37.75 \pm 2.62$ & \\
\hline \multicolumn{3}{|l|}{ Family type } \\
\hline Nuclear family & $32.80 \pm 5.81$ & \\
\hline Extended family & $34.60 \pm 4.87$ & $\mathrm{KW}=5.159$ \\
\hline Single parent & $37.75 \pm 2.62$ & $p=0.076$ \\
\hline Do you have children? & & $\mathrm{U}=1,330.50$ \\
\hline Yes & $33.85 \pm 5.51$ & $Z=-2.866$ \\
\hline No & $30.25 \pm 5.62$ & $p=0.004$ \\
\hline \multicolumn{3}{|l|}{ Number of children $(n=128)$} \\
\hline 1 & $33.57 \pm 6.05$ & \\
\hline 2 & $33.86 \pm 5.54$ & $\mathrm{KW}=4.641$ \\
\hline 3 & $35.40 \pm 3.93$ & $p=0.200$ \\
\hline 4 and more & $28.75 \pm 2.75$ & \\
\hline \multicolumn{3}{|l|}{ Educational status } \\
\hline Vocational school of health & $27.41 \pm 4.94$ & \\
\hline Associate of science & $30.60 \pm 5.58$ & $\mathrm{U}=2,094.50$ \\
\hline Bachelor's degree & $35.83 \pm 4.30$ & $Z=-2.796$ \\
\hline Other & $28.27 \pm 4.46$ & $p=0.005$ \\
\hline \multicolumn{3}{|l|}{ Occupation } \\
\hline Doctor & $33.89 \pm 5.69$ & $\mathrm{KW}=61.54$ \\
\hline Nurse & $31.76 \pm 5.50$ & $p=0.000$ \\
\hline
\end{tabular}

child sex education. In a qualitative study conducted with parents by Walker [28], some parents reported that they wanted experts of sexual health education and health professionals to provide their children with sex education. This result is in parallel with our study. Our study revealed that, because the respondents were doctors and nurses, they recognized the importance of having a specialist be involved in every kind of education in the area of healthcare. It was observed furthermore that some of the respondents who had themselves received education in this area were the ones to suggest that "experts should provide sex education." On the other hand, the second most common response that was received was that "parents should provide sex education." This response is consistent with the results of 
Table 5 Distribution of differences in the number of correct responses by opinions and approaches regarding sex education $(\mathrm{N}=159)$

\begin{tabular}{|c|c|c|}
\hline Thoughts about sex education & $\bar{X} \pm \mathrm{SD}$ & Level of significance \\
\hline \multicolumn{2}{|c|}{ Do you think it is necessary to provide sex education for children? } & \multirow{3}{*}{$\begin{array}{l}\mathrm{U}=527.50 \\
\mathrm{Z}=-1.96 \\
p=0.050\end{array}$} \\
\hline Yes & $33.43 \pm 5.65$ & \\
\hline No & $29.45 \pm 5.33$ & \\
\hline \multicolumn{2}{|c|}{ Did you receive training on children's sex education before? } & \multirow{3}{*}{$\begin{array}{l}\mathrm{U}=499.50 \\
\mathrm{Z}=-1.75 \\
p=0.079\end{array}$} \\
\hline Yes & $30.80 \pm 5.30$ & \\
\hline No & $33.31 \pm 5.71$ & \\
\hline \multicolumn{2}{|c|}{$\begin{array}{l}\text { Do you wait for your child to ask questions in order to provide information on } \\
\text { sexuality? }\end{array}$} & \multirow{3}{*}{$\begin{array}{l}\mathrm{U}=1,421.00 \\
\mathrm{Z}=-0.433 \\
p=0.665\end{array}$} \\
\hline I wait for him/her to ask questions & $33.10 \pm 5.66$ & \\
\hline I do not wait for him/her to ask questions & $33.45 \pm 6.08$ & \\
\hline \multicolumn{2}{|c|}{ Have you talked to your child about any sexuality related topic? } & \multirow{3}{*}{$\begin{array}{l}\mathrm{U}=814.50 \\
\mathrm{Z}=-8.00 \\
p=0.000\end{array}$} \\
\hline Yes & $36.59 \pm 3.14$ & \\
\hline No & $28.55 \pm 5.09$ & \\
\hline
\end{tabular}

Tuğrul and Artan's study. The small number of subjects who received this kind of education indicates that cultural mores still have an influence on people in this domain.

\section{Attitudes Towards Sexual Education}

In the study, it was determined that the most talked about topic with children was "bodily differences between genders" (100\%), whereas the least talked about topic was "masturbation" (41.1\%) among the respondents. In a study by El Shaieb and Wurtele [24] conducted with families, it was found that parents had the most difficulty in talking about masturbation and nocturnal ejaculation with their children. In a study by Diiorio et al. [29] conducted with parents, it was determined that the topic families talked least about with their children was masturbation (8-40\%). These results support our study findings.

In the study, $85.2 \%$ of the respondents reported that they waited for their children to ask relevant questions before providing them with information on sexuality. In a qualitative study by Walker [28] conducted with families, some mothers reported that they answered questions about sexuality only if children asked such questions. Family counselors state that parents should initiate conversations about human anatomy during the preschool period, and about reproduction and birth in particular by age 2 years without waiting for their children to ask questions about sexuality [18]. In our society, bringing up any topic related to sexuality is considered shameful, sinful and subjects that are avoided, not spoken out loud or mentioned in any way $[3,26]$. Studies have shown that waiting for a child to ask questions before starting with sex education leads to feelings of shyness and embarrassment because of the cultural pressures that exist. Parents need to be educated before this situation can change. The fact that there were so few respondents in our study who had received education in this area even though they were doctors and nurses is not surprising.

It was found in the study that the statement the respondents believed was the most accurate about the behavior of children in the age group 3-6 was "children aged between 5 and 6 years may try to touch their mothers' or other women's breasts" (96.2\%); the statement they believed was the least accurate was "Sexuality and sex education starts during adolescence" $(71.1 \%)$. Aral et al. [30] found that most of the parents in their study 
believed that sexual education should start in the pre-school period. This finding is consistent with our results. The data collected from the parents of children in the age group 4-6 by Eser and Çeliköz [31] in their study on "The effects of parental attitudes toward the development of sexual identity in the development of a child's sexual identity" indicated that $78.7 \%$ of the children had not tried to touch the bodies of adults.

In the study, it was determined that the number of correct answers given by the respondents regarding children's sexual development and sex education was affected by age group, marital status, the status of having children, educational status, and occupation. In parallel to increases in age, increases in education and experience as well as being married and having children are believed to cause an increase in sensitivity toward the importance of child development. The fact that $93 \%$ of our cases thought it was necessary to provide sex education for children supports our assumption. Another finding explaining this result is that considering the necessity of sex education for children and the status of talking to children on any topic related to sexuality affected the number of correct answers given by our respondents pertaining to children's sexual development and sex education.

In the study, $78.6 \%$ of the cases regarded the statement "In children aged between 5 and 6 years, girls' questions about sexuality should be answered by mothers and boys' questions should be answered by fathers" as true. In previous studies, it was demonstrated that mothers talked about sexuality to female children and fathers to male children more frequently $[32,33]$. These results support our study findings.

In the study, the statement "If you encounter a scene that includes sexuality while you are watching television with your child, possible solutions for this situation are turning off the television, switching the channel or closing your child's eyes" was regarded as true by $86.2 \%$ of the respondents and as false by $7.5 \%$. Attitudes toward topics related to sexuality within the family may affect the development of sexual identity. Excessive supervision can lead to sexual fears and the development of a sexual identity that is characterized by shyness [26].

In the study, the statement "Children do not have sexual instincts" was regarded as true by $23.3 \%$ of the respondents and as false by $61 \%$. Children start experiencing sexuality at an early age [34]. Freud argued that we possess the two basic instincts of death and sexuality at birth and that the sexual instinct is a part of the instinct to live [25, 35].

In the study, the statement "Parents are more responsible than schools in providing children with sex education" was regarded as true by $84.3 \%$ of the respondents and as false by $8.2 \%$. On the other hand, the statement "Mothers and fathers should provide children with their first information on sexuality" was regarded as true by $94.3 \%$ and as false by $5.7 \%$. A great amount of health education begins in the family. In annual surveys, children identify their parents as an important source of sex education [29]. There are findings indicating that talking about sex with parents affects children's sexual behavior during adolescence. It was reported that young people who received sex education at home started having sex later and engaged less in risky behaviors [36, 37]. In a previous study, it was determined that parents wanted to talk to their children about sexual behavior but they felt embarrassed and uncomfortable and thought that they did not have the skills or the information to talk about sex [38].

\section{Conclusion and Recommendations}

The scope of our study included doctors and nurses, who are in an important position to provide parents with information on children's sexual development and sex education and 
are a group that parents regard as sources of reference. Approximately all of our respondents thought that it is necessary to provide children with sex education, and the majority thought that sex education should be provided for children between the ages 7-12. However, in a review of our study findings, we observed that culture had an important impact on sex-related approaches and that embarrassment and shyness is very common. Due to the small number of people who receive training on sex education, approaches to sexuality and sex education are mainly affected by cultural mores. We therefore recommend that health professionals be provided with training programs on "Sex education in children ages $0-6$ years."

Acknowledgments We thank the participants who participated in this study.

Conflict of interest This study has no conflict of interest/financial disclosure.

Open Access This article is distributed under the terms of the Creative Commons Attribution License which permits any use, distribution, and reproduction in any medium, provided the original author(s) and the source are credited.

\section{References}

1. Çağdaş, A., Seçer, Z.Ş.: Anne-Baba Eğitimi (Parenting Education). Kök Yayıncılık, Başak Matbaacılık, 2. Bask1, Ankara (2006)

2. Vlachou, M., Andreou, E., Botsoglou, K., Didaskalou, E.: Bully/Victim problems among preschool children: a review of current research evidence. Educ. Psychol. Rev. 23, 329-358 (2011)

3. Çalışandemir, F., Bencik, S., Artan, I.: Sexual education of children: an overview from the past to present. Educ. Sci. 33, 14-27 (2008)

4. Matziou, V., Perdikaris, P., Petsios, K., Gymnopoulou, E., Galanis, P., Brokalaki, H.: Greek students' knowledge and sources of information regarding sex education. Int. Nurs. Rev. 56, 354-360 (2009)

5. Bulut, A., Gölbaş1, Z.: The evaluation of communication between adolescent girls and their mothers related to sexual issues. TAF Prev. Med. Bull. 8(1), 27-36 (2009)

6. Pınar, G., Doğan, N., Ökdem, Ş., Algıer, L., Öksüz, E.: Knowledge, attitudes and behavior of students related to sexual health in a private university. Tıp. Araştırmaları Derg. 7(2), 105-113 (2009)

7. Set, T., Dağdeviren, N., Aktürk, Z.: Sexuality of adolescents. Genel Tıp. Derg. 16(3), 137-141 (2006)

8. Wilkinson, V.J., Theodore, K., Raczka, R.: As normal as possible': sexual identity development in people with intellectual disabilities transitioning to adulthood. Sex. Disabil. (2014). doi:10.1007/ s11195-014-9356-6

9. Bedard, C., Zhang, H.L., Zucker, K.J.: Gender identity and sexual orientation in people with developmental disabilities. Sex. Disabil. 28, 165-175 (2010)

10. Swango-Wilson, A.: Systems theory and the development of sexual identity for individuals with intellectual/developmental disability. Sex. Disabil. 28, 157-164 (2010)

11. Brunnberg, E., Bostrom, L., Berglund, M.: Sexuality of 15/16-year-old girls and boys with and without modest disabilities. Sex. Disabil. 27, 139-153 (2009)

12. Oladunni, T.M.: Sexual behavior and practices among adolescents with disabilities in Southwest Nigeria. Sex. Disabil. 30, 289-299 (2012)

13. Ekstrand, M., Larrson, M., Von Essen, L., Tyden, T.: Swedish teenager perceptions of teenage pregnancy, abortion, sexual behavior, and contraceptive habits: a focus group study among 17-year-old female high-school students. Acta Obstet. Gynecol. Scand. 84, 980-986 (2005)

14. Bayhan, S.P., Artan, I.: Child Development and Education. Morpa Yayınları, Istanbul (2004)

15. Tuzcuoğlu, N., Tuzcuoğlu, S.: Child Sexual Education-Mother, How I Was Born? Morpa Kültür Yayınlar1, 2. Baskı, Istanbul (2004)

16. Bulut, A.: Youth health awareness, sexual education concept in Turkey. J. Child. 4(1), 8-10 (2004)

17. Artan, I.: The implementation through courses of sex education activities. Yaşadıkça Eğitim. 73, 16-19 (2002)

18. Cappello, D.: When sex ed meets parent ed: supporting parents as sexuality educators. SIECUS Rep. 29(2), 4-6 (2001) 
19. Moore, M.J., Rienzo, B.A.: Utilizing the SIECUS guidelines to asses sexuality education in one state: content scope and importance. J. Sch. Health 70(2), 56-60 (2000)

20. Tokuç, B., Berberoğlu, U., Saraçoğlu, G.V., Çelikkalp, U.: Opinions of health college students on premarital sex, induced abortions and contraceptive use of young people. Turk. J. Public Health 9(3), 166-173 (2011)

21. Bearinger, L.H., Sieving, R.E., Ferguson, J., Sharma, V.: Global perspectives on the sexual and reproductive health of adolescents: patterns, prevention, and potential. Lancet 369, 1220-1231 (2007)

22. Yurdakul, S.: Children and Sexuality. Kare Yayınları, İstanbul (2008)

23. Tuğrul, B., Artan, İ.: Çocukların cinsel eğitimi ile ilgili anne görüşlerinin incelenmesi [An examination of mothers' opinions on children's sex education]. Hacet. Üniv. Eğitim Fak. Derg. [Hacet. Univ. Fac. Educ. J.] 20, 141-149 (2001)

24. El Shaieb, M., Wurtele, S.K.: Parents' plans to discuss sexuality with their young children. Am. J. Sex. Educ. 4(2), 103-115 (2009)

25. Korkmaz Çetin, S., Bildik, T., Erermiş, S., Demiral, N., Özbaran, B., Tamar, M., Aydın, C.: Sexual behavior and sources of information about sex among male Adolescents: an 8-year follow-up. Türk. Psikiyatr. Derg. 19(4), 390-397 (2008)

26. Köksal Akyol, A.: "Psycho-sexual development", development and learning. In: Ulusoy, A. (ed.) An1 Yayıncilik, 5th edn, pp. 125-136. Ankara (2009)

27. Babacan, S.S.: The cultural and psycho-social aspects of human sexuality. Kast. Eğitim Derg. 11(1), 131-136 (2003)

28. Walker, J.L.: A qualitative study of parents' experiences of providing sex education for their children: the implications for health education. Health Educ. J. 60, 132-146 (2001)

29. Diiorio, C., Pluhar, E., Belcher, L.: Parent-child communication about sexuality: a review of the literature from 1980-2002. J. HIV/AIDS Prev. Educ. Adolesc. Child. 5, 7-32 (2003)

30. Aral, N., Akyol, K., Isık, N.: Parents to examine their thoughts about sex education. Gazi Üniv. Mesl. Eğitim Derg. 7, 1-16 (2002)

31. Eser, M., Çeliköz, N.: Impacts of parental attitude towards sexual identity development on child's sexual identity development. Procedia Soc. Behav. Sci. 1, 1408-1413 (2009)

32. Diiorio, C., Kelley, M., Hockenberry-Eaton, M.: Communication about sexual issues: mothers, fathers, and friends. J. Adolesc. Health 24(3), 181-189 (1999)

33. Diiorio, C., Resnicow, K., Dudley, W.N., Thomas, S., Wang, D.T., Van Marter, D.F., Manteuffel, B., Lipana, J.: Social cognitive factors associated with mother-adolescent communication about sex. J. Health Commun. 5(1), 41-51 (2000)

34. Gabb, J.: Sexuality education: how children of lesbian mothers 'learn' about sex/uality. Sex Educ. 4(1), 19-34 (2004)

35. Emir, S., Kanl1, E.: An investigation of the forms of primary teachers' motivating the students. Hasan Ali Yücel Eğitim Fak. Derg. 7(1), 63-79 (2010)

36. McDermott Sales, J., Milhausen, R.R., Wingood, G.M., DiClemente, R.J., Salazar, L.F., Crosby, R.A.: Validation of a parent-adolescent communication scale for use in STD/HIV prevention interventions. Health Educ. Behav. 35, 332-345 (2008)

37. Hutchinson, M.K., Wood, E.B.: Reconceptualizing adolescent sexual risk in a parent-based expansion of the theory of planned behavior. J. Nurs. Scholarsh. 39(2), 141-146 (2007)

38. Turnbull, T.: Sex and relationship education in British families: how do we move forward? Educ. Health 29(2), 35-37 (2011) 